\title{
VIP Gene Product
}

National Cancer Institute

\section{Source}

National Cancer Institute. VIP Gene Product. NCI Thesaurus. Code C136789.

A protein encoded by the VIP gene. 